\title{
Water supply project feasibilities in fringe areas of Kolkata, India
}

\author{
K. Dutta Roy ${ }^{1}$, B. Thakur ${ }^{2}$, T. S. Konar ${ }^{3}$, and S. N. Chakrabarty ${ }^{4}$ \\ ${ }^{1}$ Kolkata Metropolitan Water and Sanitation Authority, Kolkata, India \\ ${ }^{2}$ Meghnad Saha Institute of Technology, Kolkata, India \\ ${ }^{3}$ Civil Engineering Dept., Jadavpur University, Kolkata, India \\ ${ }^{4}$ Civil Engineering Dept., Jadavpur University, Kolkata, India \\ Received: 30 August 2010 - Published in Drink. Water Eng. Sci. Discuss.: 22 September 2010 \\ Revised: 11 December 2010 - Accepted: 30 December 2010 - Published: 17 January 2011
}

\begin{abstract}
Water supply management to the peri-urban areas of the developing world is a complex task due to migration, infrastructure and paucity of fund. A cost-benefit methodology particularly suitable for the periurban areas has been developed for the city of Kolkata, India. The costs are estimated based on a neural network estimate. The water quality of the area is estimated from samples and a water quality index has been prepared. A questionnaire survey in the area has been conducted for relevant information like income, awareness and willingness to pay for safe drinking water. A factor analysis has been conducted for distinguishing the important factors of the survey and subsequent multiple regressions have been conducted for finding the relationships for the willingness to pay. A system dynamics model has been conducted to estimate the trend of increase of willingness to pay with the urbanizations in the peri-urban areas. A cost benefit analysis with the impact of time value of money has been executed. The risk and uncertainty of the project is investigated by Monte Carlos simulation and tornado diagrams. It has been found that the projects that are normally rejected in standard cost benefit analysis would be accepted if the impacts of urbanizations in the peri-urban areas are considered.
\end{abstract}

\section{Introduction}

\subsection{Background}

The urban population is increasing at a rapid rate. In Asia, about $37 \%$ of the population was living in urban space in the year 2000. By 2030, the percentage is expected to reach about $54 \%$ which is equivalent to about $0.58 \%$ increase in each year. This is a significant departure from the trend of the same population group in 1950 when the annual average increase was only about $0.29 \%$ (Cohen, 2006). The trend is more pronounced in Kolkata (earlier called Calcutta). The population has increased from 11.02 million in 1991 to 13 million in 2001 indicating about $1.8 \%$ annual growth rate (Bannerjee and Das, 2006). Such an urbanization rate generated a tremendous pressure on civic facilities like water supply.

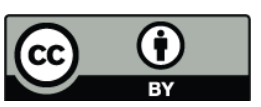

Correspondence to: B. Thakur (b2981975@yahoo.co.in)
World Health Organization, in a half a century old study, found that only $12 \%$ of urban population in India had house connections and $18 \%$ used public stand post for water. The remaining $70 \%$ had no facility for piped water (Dietrich and Henderson, 1963). The same study also found that in all most all of the 75 developing countries that were within the study scope, the water works developments are too slow to match the future needs. In a decade later, International Bank for Reconstruction and International Development Association (IBRD) started financing for the water supply system. Improvements like construction of mains, reservoirs, booster stations and small groundwater based systems in the fringe areas of Kolkata have been initiated (IBRD, 1973). Such ground water based small systems have become a norm for fringe areas of Kolkata for many years mainly because of lesser investments and smaller gestation periods. The maintenance cost for small ground water supply is relatively high (Dutta Roy and Chakravarti, 2006). In Kolkata, the ground water was found to be bacteria free but showed high concentrations of chlorides and other chemicals. Hardness and Iron $(\mathrm{Fe})$, Chlorine $(\mathrm{Cl})$, and sulfates increase from north to south 
Table 1. Methodology tools.

\begin{tabular}{|c|c|c|c|}
\hline Steps & Tools & Input & Output \\
\hline \multirow[t]{2}{*}{ Technical analysis } & CCME Water & 1. Chemical data of water & \multirow[t]{2}{*}{ Quality index for potable water } \\
\hline & Quality Index & 2. Indian standard limits & \\
\hline \multirow[t]{6}{*}{ Cost analysis } & Present value analysis & 1. Fund flows & \multirow[t]{3}{*}{ Present value of cost } \\
\hline & & 2. Service life & \\
\hline & & 3. Interest rate & \\
\hline & ANN model estimate & 1. Land rent & Cost estimate of the booster stations \\
\hline & & 2. Population & \\
\hline & & 3. Distance from plant & \\
\hline \multirow[t]{5}{*}{ Benefit analysis } & Factor analysis for & 1. Variables affecting WTP & Ten nos. selected based on \\
\hline & variable selections & 2. WTP survey data & actual impact on WTP \\
\hline & $\begin{array}{l}\text { Multiple regression for } \\
\text { WTP estimate }\end{array}$ & $\begin{array}{l}\text { Selected variables values } \\
\text { from WTP survey }\end{array}$ & $\begin{array}{l}\text { Relationships among WTP } \\
\text { and variables }\end{array}$ \\
\hline & Dynamic simulation for & 1. Increase of built-up area & \multirow{2}{*}{ Forecast of WTP increase with time } \\
\hline & WTP forecast in fringes & 2. WTP and income survey & \\
\hline \multirow[t]{2}{*}{ Cost benefit analysis } & $\begin{array}{l}\text { Monte Carlo's simula- } \\
\text { tion for risk analysis }\end{array}$ & $\begin{array}{l}\text { Input variations like family size, } \\
\text { inflation, interest }\end{array}$ & Distributions of the net present value \\
\hline & $\begin{array}{l}\text { Sensitivity analysis } \\
\text { for uncertainty }\end{array}$ & Net present value relationship data & $\begin{array}{l}\text { Tornado diagram for sensitivity } \\
\text { of variables }\end{array}$ \\
\hline
\end{tabular}

side of Kolkata. Recent studies also show that the groundwater in some areas contains arsenic, lead, and cadmium in excess of the levels prescribed by the WHO for drinking water (KMC, 2006). Experience and awareness have increased the demand of piped surface water in the fringe area. The policy makers now shun away from ground water sources because of its detrimental impacts. For example, Asian Development bank (ADB) has recently sanctioned a 230 Mil US\$ loan for environmental improvement in Kolkata which includes construction of 8500 public stand posts but ground water based small water supply systems have not been financed (KMC, 2007).

Many of the users in the fringe areas find the ground water unpalatable and regularly purchase surface water for drinking from unorganized sector. Llorente and Zerah (2003) found that in New Delhi, India the water suppliers in such areas enjoyed a sizable market demand. Gessler and Brighu (2008) also found that in Jaipur, India the alternative providers supplied good quality water in tankers or camel-powered cart in peripheral areas of the city.

Water is traditionally supplied free of cost in Kolkata. Costs for the water supply are clubbed to the property tax (Ruet, 2002). Roy et al. (2003) reported that the Kolkata Municipal Corporation (KMC) grants about $75 \%$ subsidy to water supply. As a result, the water supply department is resource starved and soft international loans are availed for water supply infrastructures. However, international funding agencies require cost benefit analysis (CBA) and the author- ity is obligated to prepare an explicit CBA as per best management practice. The development of such a CBA for the funding agencies has been found to be daunting for want of data and interdisciplinary nature of applications.

\subsection{Methodology}

The objective of this study is to develop a methodology that can be effectively used for development of a CBA for water supply projects in the peri-urban areas of the cities in India. The CBA should have sufficient details for catering the requirements of the international funding agencies. In typical CBA studies in India, the benefits are estimated from willingness to pay (WTP) studies conducted in the service area. It seems that the values obtained from such a WTP study in the peri-urban area would be inaccurate in the long run. The effect of rapid urbanization in the fringe areas should be integrated to the CBA study. In this paper, a CBA methodology with special reference to fringe area of the city that is under transition to piped water supply has been investigated.

In order to develop an appropriate CBA a number of steps from varities of technical fields have been used as shown in the block diagram in Fig. 1. The steps essential for the CBA are indicated in blocks in Fig. 1. A number of tools as shown in Table 1 have been used to complete the steps presented in Fig. 1. The explanation of these steps as well as the tools used in CBA are presented herein. 


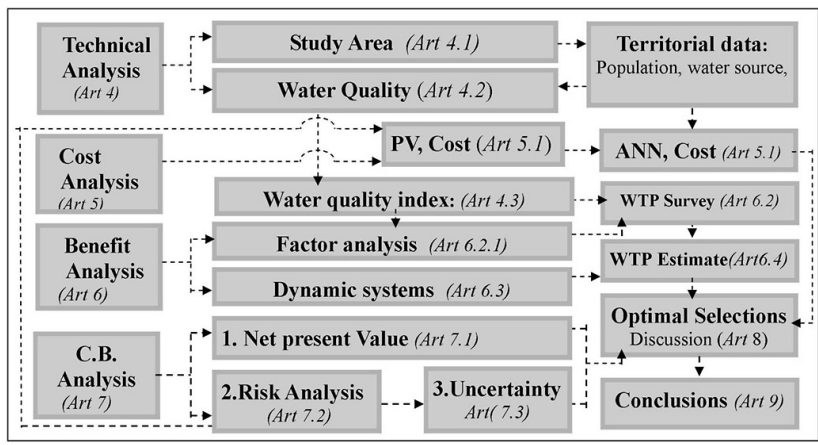

Figure 1. Block Diagram for the CBA.

\section{Existing status}

\subsection{Previous study}

The present authors investigated about the water supply network feasibilities in Kolkata in an earlier study (Dutta Roy et al., 2010). In the study, artificial neural network (ANN) have been trained for estimation of booster pumping station costs based on size, land rent and distance from the treatment plant. The benefit of the project is estimated from the willingness to pay survey conducted among beneficiaries within the Kolkata city. The costs and benefits occurred during the project life have been reduced to the present value for comparison. The variability of data has been studied with the help of Monte Carlo's simulation, uncertainty analysis and tornado diagram. The study has resulted in two key observations. Firstly, the net present value (NPV) of a booster pumping station is reduced to about zero at a distance of $20 \mathrm{~km}$ from the treatment plant. Secondly, the NPV is heavily dependent on the social discount and inflation rate. Accurate predictions of long term discount and inflation rate are really in the domain of the economists. Apart from it the study seems to have other latent issues in reference to its application to the fringe areas as explained in the following.

\subsection{Willingness to pay}

The monetary benefit from the project is based on WTP survey conducted on the beneficiaries. A number of WTP surveys have been conducted for water supply benefits in Kolkata (World Bank, 2001; Roy et al., 2003; Guha, 2007; Majumdar and Gupta, 2009). In addition, the authors also conducted a WTP survey in connection with the previous study (Dutta Roy et al., 2010). Each of these studies was conducted among the residents who had access to piped surface water. The dwellers living in the fringe areas of the city does not have access of the piped surface water. They use ground water either from bore/tube wells or use the public stand posts served by ground water based small systems. Users suffer from the disadvantages like hardness and iron contents. Many of these users buy surface water for drinking/cooking.
Ground water in some of the fringe areas contains harmful chemicals like arsenic (Bhattacharya et al., 1997; Chatterjee et al., 1995). The user groups who suffer from water quality have already revealed their economic choices by purchasing water. The negative experience from hardness and iron content in ground water is likely to alter the WTP among those living in the fringe areas. The rising awareness about the harmful chemical in ground water may also change the WTP with time. The WTP of the previous studies were all conducted among the dwellers enjoying the piped surface water. The WTP in the fringe areas might be different which should be used in the CBA for water supply projects in these areas. Such issues are investigated in this study.

\subsection{Issues}

Efforts have been made in many countries for standardization of CBA. For example, the Office of Management and Budget $(\mathrm{OMB})$ in US issued guidelines for CBA and risk assessment (Kopp et al., 1997). European Union started TECHNEAU, an integrated project funded by the European Commission that had a mandate to develop CBA for water supply system (Baffoe-Bonnie et al., 2006) and published guides (Florio, 2006). These studies do not specifically concentrate into urban-rural borderline where urbanization is taking place rapidly. The dwellers in fringe areas who purchase surface water reveal economic preferences that are not discernable in benefits assessed by willingness to pay (WTP) method conducted within Kolkata where water is supplied free of cost. The present paper has investigated the issues related to CBA of supplying piped surface water to these periurban users.

\section{Technical analysis}

\subsection{Study area}

The urbanization is taking place rapidly in the study area. Bhatta, Saraswati et al. (2010) estimated the degree-offreedom and degree-of-sprawl towards the analysis of urban growth in Kolkata from satellite images of 15 years. Bhatta (December 2009) analyzed the urban growth boundary for the city of Kolkata. The satellite image data were used to model the growth boundary of Kolkata for the years 2020 and 2035. The proposed model discouraged scattered development and increase in urban growth rate. They proposed a plan with polycentric urban blobs into a monocentric tract. In order to monitor the urban growth from remote sensing, researchers have attempted the concept of Shannon's entropy for determining the dispersion of built-up land growth. The concept is applied to several Indian cities like Pune (Sekhar, 2010), Hyderabad (Lata et al., 2010), Mangalore (Sudhira, Ramachandra et al., 2004) and Indore (Antony, Kumar et al., 2007) with encouraging results. Bhatta (September 2009) applied Shannon's entropy model to Kolkata's urban growth. 
Table 2. Water pumping stations in Kolkata and southern fringes.

\begin{tabular}{lllrrr}
\hline Supply & S1 & Station Name & Tributary pop. (000) & Tank (MG) & Supply (MGD) \\
\hline GRWW & 1 & GRWW Ph1 & & & \\
& 2 & GRWW Ph2 & 579.6 & NA & 60.00 \\
& 3 & Behala & 550.9 & 3.5 & 9.00 \\
& 4 & Mahestala & 236.1 & 5.0 & 10.00 \\
& 5 & Ranikuthi & 241.3 & 3.5 & 7.00 \\
& 6 & Garfa & 185.9 & 3.5 & 7.00 \\
& 7 & Kalighat & 319.7 & 4.0 & 8.00 \\
& 8 & Bansdroni & 122.7 & 2.0 & 4.00 \\
& 9 & Pujali & 34.7 & 0.70 & 2.10 \\
\hline & & Total & 2630.9 & 22.20 & 107.10 \\
\hline DRWW & DRWW Direct & 757.8 & NA & 21 \\
& 10 & Kamagazi & 341.8 & 1.0 & 3 \\
& 11 & Begampur & 419.7 & 1.0 & 3 \\
& 12 & Krishnamohanpur & 47.4 & 1.0 & 30 \\
\hline
\end{tabular}
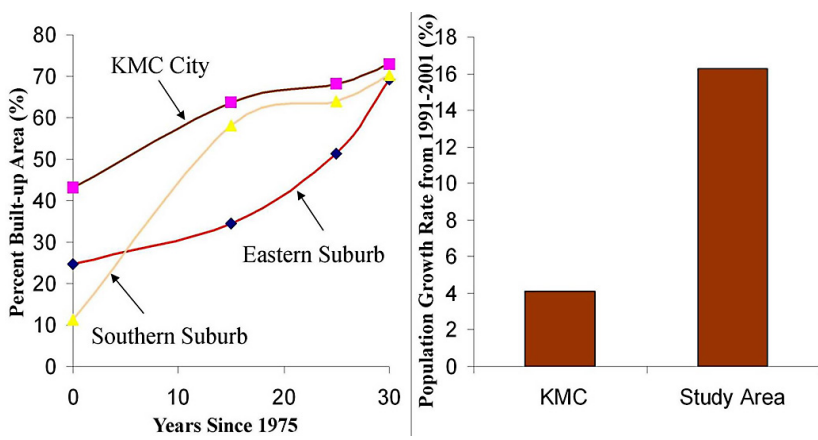

Figure 2. Urban growths in fringes of Kolkata.

He found higher growth rate of the built up area in the present study location that is the southern and eastern fringes of the city. The increase in built up area derived from satellite data by Bhatta (September 2009) is presented in Fig. 2. The population growth in Kolkata Municipal Corporation (KMC) and areas within the present study area as obtained from census records are also presented in Fig. 2. The Fig. 2 would indicate that population growth in the study area is increasing at a higher rate than that of the Kolkata city limits exerting a greater demand for drinking water services in the study area.

The water supply scheme based on ground water based small systems in the peri-urban area of Kolkata was initiated in about three decades earlier (IBRD, 1973). The divisions of ground and surface water distribution as observed in 1995 were presented by Basu and Main (2001). The population in the study area either uses ground water based small systems or individual bore wells. They are subjected to the detrimental effects of the ground water. Many of them purchase drinking water from vendors. Some of these areas are now in a transition stage for piped surface water from the two water works namely the Garden Reach Water Works (GRWW) and the Dakshin Roypur Water Works (DRWW). GRWW is administratively designated only for the city of Kolkata and DRWW serves the peri-urban areas. The details of the water works are presented in Table 2.

\subsection{Water quality}

Water quality standards are not a fixed world wide standard. It varies significantly even in a country with the passage of time. In the setting of standards, competent agencies make political, economical, technical and scientific decisions about how the water will be used. For example, the US act requires reviewing the water quality standards in every three years (US EPA, 2010). Indian standard (CPHEEO, 1999) has specified a series of requirements for potable water standards.

The Septic/Imhoff tank is the common form of sewage disposal method in the study area. Effluents are generally dispersed to ground through soak pits. Ground water up to a depth of about 15M is not potable for contamination (Sahu and Sikder, 2009). In Kolkata, a Quaternary aquifer is sandwiched between two clay sequences (Sahu and Sikder, 2009). It starts from a depth of about $50 \mathrm{~m}$. The depth of aquifer is about $300 \mathrm{~m}$ below which the bottom clay bed of Pliocene age occurs (Sikdar et al., 2001). The ground water is usually drawn from a depth of about 100 to $300 \mathrm{~m}$ depths. The Central Ground Water Board (CGWB, 2010) in India indicated salinity and arsenic as the major problem for ground water in Kolkata. Users in the study area depend on ground water because it is mostly safe from biological contamination which at least prevents the epidemics. However, ground 
Table 3. Water quality observed in southern fringes of Kolkata.

\begin{tabular}{|c|c|c|c|c|c|c|c|c|c|}
\hline Source & Area & $\mathrm{pH}$ & $\begin{array}{l}\text { Chloride } \\
(\mathrm{mg} / \mathrm{l})\end{array}$ & $\begin{array}{l}\text { Hardness } \\
\left(\mathrm{mg} / \mathrm{l}_{3}\right)\end{array}$ & $\begin{array}{l}\text { Iron } \\
(\mathrm{mg} / \mathrm{l})\end{array}$ & $\begin{array}{l}\text { Arsenic } \\
(\mathrm{mg} / \mathrm{l})\end{array}$ & $\begin{array}{l}\text { Fluoride } \\
(\mathrm{mg} / \mathrm{l})\end{array}$ & $\begin{array}{l}\text { Coliform } \\
(\mathrm{N} / 100 \mathrm{ml})\end{array}$ & WQI \\
\hline \multirow{2}{*}{ Piped surface water } & W. Fringe Behala & $\begin{array}{l}7.04 \\
( \pm 0.07)\end{array}$ & $\begin{array}{l}15.65 \\
( \pm 1.55)\end{array}$ & $\begin{array}{l}4.80 \\
( \pm 2.77)\end{array}$ & $\mathrm{BDL}$ & BDL & $\mathrm{BDL}$ & 0 & 91.10 \\
\hline & E.Fringe Mukunda. & $\begin{array}{l}7.03 \\
( \pm 0.05)\end{array}$ & $\begin{array}{l}15.98 \\
( \pm 1.20)\end{array}$ & $\begin{array}{l}5.00 \\
( \pm 1.58)\end{array}$ & $\mathrm{BDL}$ & $\mathrm{BDL}$ & $\mathrm{BDL}$ & 0 & $\begin{array}{l}91.10 \\
\text { Good }\end{array}$ \\
\hline \multirow{2}{*}{ Pond } & W. Fringe Behala & $\begin{array}{l}7.02 \\
( \pm 0.07)\end{array}$ & $\begin{array}{l}58.60 \\
( \pm 6.02)\end{array}$ & $\begin{array}{l}20.20 \\
( \pm 1.64)\end{array}$ & $\mathrm{BDL}$ & $\mathrm{BDL}$ & $\mathrm{BDL}$ & $\begin{array}{l}3900 \\
( \pm 291.6)\end{array}$ & 39.00 \\
\hline & E.Fringe Mukunda. & $\begin{array}{l}7.03 \\
( \pm 0.09)\end{array}$ & $\begin{array}{l}90.60 \\
( \pm 5.77)\end{array}$ & $\begin{array}{l}29.20 \\
( \pm 2.39)\end{array}$ & $\mathrm{BDL}$ & $\mathrm{BDL}$ & $\mathrm{BDL}$ & $\begin{array}{l}3800 \\
( \pm 158.1)\end{array}$ & $\begin{array}{l}38.60 \\
\text { Poor }\end{array}$ \\
\hline \multirow{2}{*}{ Open Well } & W. Fringe Behala & $\begin{array}{l}7.01 \\
( \pm 0.02)\end{array}$ & $\begin{array}{l}23.41 \\
( \pm 3.30)\end{array}$ & $\begin{array}{l}108.00 \\
( \pm 8.37)\end{array}$ & $\begin{array}{l}0.14 \\
( \pm 0.05)\end{array}$ & $\begin{array}{l}\text { BDL } \\
( \pm)\end{array}$ & $\begin{array}{l}\text { BDL } \\
( \pm)\end{array}$ & $\begin{array}{l}1760 \\
( \pm 167.3)\end{array}$ & 35.70 \\
\hline & E.Fringe Mukunda. & $\begin{array}{l}7.06 \\
( \pm 0.02)\end{array}$ & $\begin{array}{l}44.01 \\
( \pm 2.47)\end{array}$ & $\begin{array}{l}158.00 \\
( \pm 8.37)\end{array}$ & $\begin{array}{l}0.16 \\
( \pm 0.05)\end{array}$ & BDL & BDL & $\begin{array}{l}1620 \\
( \pm 178.9)\end{array}$ & $\begin{array}{l}38.80 \\
\text { Poor }\end{array}$ \\
\hline \multirow{2}{*}{ Piped Gro-und water } & W. Fringe Behala & NA & NA & NA & NA & NA & NA & NA & NA \\
\hline & E.Fringe Mukunda. & $\begin{array}{l}7.36 \\
( \pm 0.03)\end{array}$ & $\begin{array}{l}173.30 \\
( \pm 5.32)\end{array}$ & $\begin{array}{l}318.60 \\
( \pm 5.59)\end{array}$ & $\begin{array}{l}0.88 \\
( \pm 0.08)\end{array}$ & BDL & BDL & 0 & $\begin{array}{l}60.80 \\
\text { Marg. }\end{array}$ \\
\hline \multirow{2}{*}{ Tube well } & W. Fringe Behala & $\begin{array}{l}7.53 \\
( \pm 0.10)\end{array}$ & $\begin{array}{l}48.21 \\
( \pm 5.91)\end{array}$ & $\begin{array}{l}173.20 \\
( \pm 5.07)\end{array}$ & $\begin{array}{l}0.70 \\
( \pm 0.27)\end{array}$ & BDL & $\mathrm{BDL}$ & 0 & $\begin{array}{l}70.90 \\
\text { Fair }\end{array}$ \\
\hline & E.Fringe Mukunda. & $\begin{array}{l}7.52 \\
( \pm 0.08)\end{array}$ & $\begin{array}{l}295.54 \\
( \pm 8.99)\end{array}$ & $\begin{array}{l}413.20 \\
( \pm 7.79)\end{array}$ & $\begin{array}{l}1.26 \\
( \pm 0.05)\end{array}$ & $\mathrm{BDL}$ & $\mathrm{BDL}$ & 0 & $\begin{array}{l}48.60 \\
\text { Marg. }\end{array}$ \\
\hline Standards & Acceptable Limit & $7.0-8.5$ & 200 & 200 & 0.10 & 0.01 & 1.00 & 0 & \\
\hline
\end{tabular}

Note 1: The acceptable limits prescibed in Indian standards (CPHEEO-2009) are presented in the table.

Note 2: Standard deviations where applicable are presented under the mean in parenthesis.

water in the study area suffers from other disadvantages like hardness and iron. Expensive control methods that are not economically feasible in large scale in Kolkata are necessary to contain hardness and iron. Users naturally have the preference for treated surface water.

The water quality as available to the users has been estimated from sample survey. Several types of potable water that are consumed in the peri-urban areas of Kolkata are collected. The sources and areas are detailed in Table 3. For each location five numbers of samples were tested for each of the potable water types. The acceptable limits under the Indian standard (CPHEOO 2010) are also shown in Table 3 for comparison.

Water samples collected from the study area were tested using standard laboratory procedures as per provisions of Standard Methods for the Examination of Water and Wastewater (APHA, 1995). A digital $\mathrm{pH}$ meter was used for measuring the $\mathrm{pH}$. The Chloride content $\left(\mathrm{as}^{-} \mathrm{Cl}^{-}\right.$) was estimated by Mohr's method. Hardness (as $\mathrm{CaCO}_{3}$ ) was determined through EDTA method. Iron and Fluoride concentrations were determined by colourimetric procedure. Arsenic was measured by a spectrophotometer. Total coliform was determined by fermentation technique and results were reported as MPN (Most Probable Number) of organisms present. The results from the tests were presented in Table 3.

\subsection{Water quality index}

Water quality index (WQI) is a tool for simplifying the reporting of water quality data. Traditional reports similar to that of Table 3 consist of variable-by variable report which is of value to experts. It supplies a wealth of data but could be overwhelming to non-chemists. For example, the Indian code for drinking water (BIS10500-1991) has more than 30 variables. The managers and decision makers may still wish to have a simpler measurement for overall representation of water quality. Indexing is a tool for such representations. There is no single measure that can describe overall water quality for a body of water. Although there is no globally accepted composite index of water quality, some authorities are using, aggregated water quality data in the development of water quality indices (UNEP, 2007). Most water quality 
indices rely on standardizing and weighted average of parameters according to their perceived importance to overall water quality (Sargaonkar and Deshpande, 2003).

The water quality index proposed by the Canadian Council of Ministers of the Environment (CCME) is a standardized and flexible index used in Canada and in other countries (CCME 2001). It was developed by the environment department of Canada after unifying a number of provincial indexes. The index was standardized against the provisions of the Indian drinking water standards (BIS10500-1991) for this study. The software (CCME 2001) developed by the Canadian government was used. Similar indexing system has been used in Nagpur (Ramakrishnaiah et al., 2009) and Karanataka (Rajankar et al., 2009), India.

The water quality index is based on the CCME method (CCME, 2001). There are three factors namely scope, frequency and amplitude in the index that are scaled to a range between 0 and 100. The estimated WQI values ranges from 0 to 100 that are classified into five water quality categories namely excellent (95-100), good (80-94), fair (65$79)$, marginal (45-64) and poor (0-44). The WQI of the samples was estimated by the recommended software (CCME, 2001) and reported in Table 3. The acceptable limits of the variables in the sample are based on the Indian standard (CPEEHO, 1999) and is also reported in Table 3.

\section{Costing}

Life cycle costing (LCC) is usually adopted for CBA. It is the total cost of ownership of an asset including its cost of acquisition, operation, maintenance, conversion, and/or decommission (SAE, 1999). Since outflows occur over multiple time periods it is reduced to a present value using the standard principle of time value of money for standardized LCC methodology such as by US Government (Fuller and Petersen, 2002). The risk and uncertainty of cash flows are also considered in LCC (Emblemsvåg, 2003). A flow diagram of the life cycle cost of a typical water supply installation is presented in Fig. 3. The components of acquisition and annual sustenance costs are presented. In order to compress the stream of cash flows the economic adjustment components are considered. The components required for managing the variability of outcomes are also presented in Fig. 3.

The present value estimate that has been used in relation to this study is presented in Eq. (1).

$C p=\frac{\sum_{t=1}^{L} \frac{C_{t}(1+r)^{t}}{(1+i)^{t}}}{\sum_{t=1}^{L c} Q t}+\sum_{t=1}^{L} \frac{\frac{O_{t}(1+r)^{t}}{Q_{t}}}{(1+i)^{t}}$

Where, $C p=$ Present value of cost in INR/Kl, $i=$ Discount rate at year $t, C t=$ Acquisition costs in INR incurred at year $t$, $O t=$ Sustenance costs in INR incurred at year $t, Q t=$ Quantity of water in $\mathrm{Kl}$ generated at year $t, L=$ Expected life of

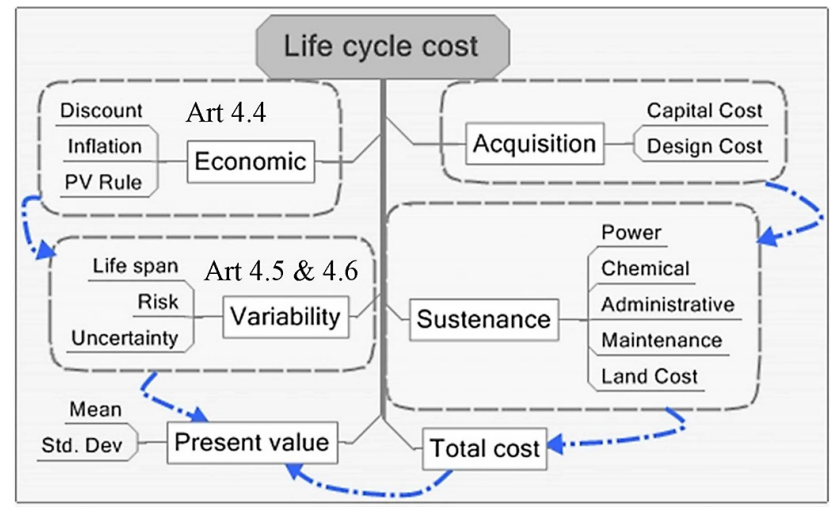

Figure 3. Block diagram for cost estimate.

the facilities, $i=$ Discount rate at year $t$ and $r=$ inflation rate at year $t$.

The inputs in Eq. (1) would require complete technical design, drawing and specifications for a specific installation and estimation of all operations of the facility which might be exhaustive, time consuming and sometimes infeasible for new projects. In order to circumvent such issues data driven models like artificial neural network (ANN) has been proposed for cost estimate (Adeli, 2001; Boussabaine, 1996). The ANN is a mathematical model of theorized brain activity for processing an existing dataset (Zurada, 1992). Similar ANN techniques have been used in this case for estimating the cost of water supply.

\subsection{Cost estimate}

The costs of the facilities have been collected from the records of the concerned departments of GRWW in an earlier study. We (Dutta Roy et al., 2010) trained an ANN model among the existing cost data of the GRWW network with the help of NeuroSolutions software (NeuroDimensions, 2009) and derived a cost model. The ANN cost model was based on three input factors namely land rent, serving population and the distance from the treatment plant. The model is applied to the DRWW network and costs for the booster stations are estimated. The inputs as well as the ANN findings are presented in Table 4.

\section{Benefit}

\subsection{Benefit analysis}

The benefit of the project is first estimated based on a willingness to pay (WTP) survey which is fairly common even in Kolkata (World Bank, 2001; Roy et al., 2003; Guha, 2007; Majumdar and Gupta, 2009; Dutta Roy et al., 2010). The consumer's spending capacity and experience and awareness about a product have an impact on the WTP. As a result of urbanizations the population in the study area is increasing 
Table 4. ANN Results of the DRWW Network.

\begin{tabular}{llccccc}
\hline Sl & Station & Tributary pop. (000) & Land rent (INR) & Supply (Kl/day) & Distance (KM) & ANN Cost (INR/Kl) \\
\hline 10 & Kamalgazi & 341.803 & 608986 & 51270.45 & 57.92 & $5.2990 \pm 0.2161$ \\
11 & Begampur & 419.718 & 341032 & 62957.70 & 42.48 & $4.8360 \pm 0.2166$ \\
12 & Krishnamohanpur & 474.514 & 243594 & 71177.10 & 41.15 & $4.7970 \pm 0.2056$ \\
\hline
\end{tabular}

Table 5. Correlation matrix.

\begin{tabular}{|c|c|c|c|c|c|c|c|c|c|c|c|c|c|c|c|c|c|c|c|c|c|c|}
\hline & $\begin{array}{l}\text { WQI } \\
\text { BFW }\end{array}$ & $\begin{array}{r}\text { WQI } \\
\text { DC }\end{array}$ & $\begin{array}{l}\text { Fam } \\
\text { Size }\end{array}$ & $\begin{array}{l}\text { Avg } \\
\text { Age }\end{array}$ & $\begin{array}{r}\text { High } \\
\text { Age }\end{array}$ & $\begin{array}{l}\text { Low } \\
\text { Age }\end{array}$ & $\begin{array}{l}\text { Avg } \\
\text { Edu }\end{array}$ & $\begin{array}{r}\text { High } \\
\text { Edu }\end{array}$ & $\begin{array}{l}\text { Low } \\
\text { Edu }\end{array}$ & $\begin{array}{l}\text { Total } \\
\text { Incm }\end{array}$ & $\begin{array}{r}\text { PC } \\
\text { Incm }\end{array}$ & $\begin{array}{r}\text { Exp } \\
\text { BFW }\end{array}$ & $\begin{array}{l}\text { Dfclt } \\
\text { BFW }\end{array}$ & $\begin{array}{c}\text { Exp } \\
\text { DC }\end{array}$ & $\begin{array}{r}\text { Dfclt } \\
\text { DC }\end{array}$ & $\begin{array}{r}\text { Buy } \\
\text { Amnt }\end{array}$ & $\begin{array}{r}\text { Buy } \\
\text { Mony }\end{array}$ & $\begin{array}{l}\text { Awr } \\
\text { Path }\end{array}$ & $\begin{array}{l}\text { Awr } \\
\text { Arsn }\end{array}$ & $\begin{array}{l}\text { Awr } \\
\text { Iron }\end{array}$ & $\begin{array}{l}\text { Awr } \\
\text { Total }\end{array}$ & WTP \\
\hline WQI BFW & 1 & & & & & & & & & & & & & & & & & & & & & \\
\hline WQI DC & 0.17 & 1 & & & & & & & & & & & & & & & & & & & & \\
\hline Fam Size & -0.01 & 0.16 & 1 & & & & & & & & & & & & & & & & & & & \\
\hline Avg Age & -0.17 & 0.40 & -0.12 & 1 & & & & & & & & & & & & & & & & & & \\
\hline High Age & -0.09 & 0.40 & 0.48 & 0.64 & 1 & & & & & & & & & & & & & & & & & \\
\hline Low Age & -0.15 & 0.11 & -0.53 & 0.66 & 0.04 & 1 & & & & & & & & & & & & & & & & \\
\hline Avg Edu & -0.23 & -0.27 & -0.23 & 0.04 & -0.07 & 0.10 & 1 & & & & & & & & & & & & & & & \\
\hline High Edu & -0.19 & -0.10 & 0.10 & 0.10 & 0.24 & -0.10 & 0.71 & 1 & & & & & & & & & & & & & & \\
\hline Low Edu & -0.11 & -0.32 & -0.41 & -0.13 & -0.36 & 0.10 & 0.78 & 0.36 & 1 & & & & & & & & & & & & & \\
\hline Total Incm & -0.08 & 0.25 & -0.04 & 0.16 & 0.16 & 0.05 & 0.42 & 0.39 & 0.33 & 1 & & & & & & & & & & & & \\
\hline PC Incm & -0.04 & 0.16 & -0.37 & 0.22 & -0.07 & 0.33 & 0.48 & 0.30 & 0.48 & 0.73 & 1 & & & & & & & & & & & \\
\hline Exp BFW & -0.12 & -0.40 & 0.16 & -0.05 & 0.05 & -0.12 & 0.08 & 0.16 & 0.11 & -0.10 & -0.11 & 1 & & & & & & & & & & \\
\hline Dfclt BFW & -0.07 & -0.04 & 0.22 & -0.24 & -0.04 & -0.23 & -0.14 & -0.09 & -0.12 & -0.01 & -0.10 & 0.13 & 1 & & & & & & & & & \\
\hline Exp DC & -0.10 & -0.52 & 0.09 & -0.11 & -0.03 & -0.12 & 0.14 & 0.13 & 0.20 & -0.09 & -0.09 & 0.85 & 0.05 & 1 & & & & & & & & \\
\hline Dfclt DC & -0.15 & -0.85 & -0.11 & -0.35 & -0.38 & -0.13 & 0.26 & 0.13 & 0.31 & -0.10 & -0.03 & 0.41 & 0.22 & 0.44 & 1 & & & & & & & \\
\hline Buy Amnt & 0.09 & 0.78 & 0.36 & 0.30 & 0.44 & -0.04 & -0.18 & -0.01 & -0.31 & 0.13 & -0.05 & -0.30 & -0.01 & -0.40 & -0.67 & 1 & & & & & & \\
\hline Buy Mony & -0.02 & 0.61 & 0.31 & 0.25 & 0.35 & -0.04 & -0.09 & 0.09 & -0.24 & 0.10 & -0.05 & -0.27 & 0.01 & -0.34 & -0.51 & 0.88 & 1 & & & & & \\
\hline Awr Path & 0.07 & 0.48 & -0.07 & 0.40 & 0.25 & 0.29 & 0.02 & 0.02 & 0.01 & 0.11 & 0.14 & -0.20 & -0.10 & -0.20 & -0.48 & 0.31 & 0.22 & 1 & & & & \\
\hline Awr Arsn & -0.05 & 0.36 & -0.11 & 0.29 & 0.22 & 0.16 & 0.09 & 0.06 & 0.09 & 0.06 & 0.11 & -0.10 & -0.01 & -0.01 & -0.42 & 0.25 & 0.14 & 0.57 & 1 & & & \\
\hline Awr Iron & 0.05 & 0.57 & -0.01 & 0.31 & 0.26 & 0.11 & -0.05 & 0.03 & -0.06 & 0.14 & 0.13 & -0.21 & -0.01 & -0.16 & -0.55 & 0.37 & 0.22 & 0.70 & 0.78 & 1 & & \\
\hline Awr Total & -0.00 & 0.53 & -0.05 & 0.37 & 0.29 & 0.18 & 0.01 & 0.04 & 0.00 & 0.12 & 0.13 & -0.18 & -0.03 & -0.13 & -0.55 & 0.35 & 0.23 & 0.82 & 0.90 & 0.94 & 1 & \\
\hline WTP & -0.09 & 0.01 & -0.21 & 0.17 & 0.06 & 0.17 & 0.56 & 0.43 & 0.45 & 0.64 & 0.75 & -0.02 & -0.07 & 0.03 & 0.03 & -0.04 & -0.01 & 0.04 & 0.12 & 0.03 & 0.07 & 1 \\
\hline
\end{tabular}

rapidly. The migrating residents are experiencing the ground water piped supply. The WTP for ground water piped supply in the peri-urban area is subjected to change because of actual experience and changing income profile among the population in the study area with the passage of time. In addition, the presence of harmful chemicals like arsenic in the study area has been published in technical literature and media. The spending capacity, experience and awareness among the residents are increasing that is expected to change the WTP for ground water piped supply with the passage of time in the study area.

Turpie (2003), in a study about valuation of biodiversity in South Africa, found that the WTP for conservation have changed when the respondents were informed about the risks. Brouwer (2006) found that WTP for bathing water after a draught experience is not the same as before. In this case, the WTP for ground water in the peri-urban area is expected to change with time because of factors like increase in the average income profile for urbanization in the area, negative experience for hardness and iron content and additional awareness about harmful chemicals like arsenic in ground water. The expected change of WTP is modeled by dynamic system analysis.

\subsection{WTP survey}

A WTP survey was carried out for estimating the consumer willingness to pay for water among 201 samples in the study area. In addition to WTP, data was collected for 21 other variables likely to influence the consumer WTP. A correlation matrix for these variables (Pearson) was calculated assessing the underlying correlations between these variables and is presented in Table 5. It is observed that two variables viz. WQI bathing/washing and difficulty for bathing/washing are poorly correlated (Pearson correlation coefficient $<0.30$ ) with other variables. Since the variables are poorly correlated these are omitted from further analysis.

\subsubsection{Factor analysis}

A principal component analysis followed by a varimax rotation carried out on remaining 18 variables using SPSS (2009) for determining the underlying factors of WTP. The analysis was run following the Kaiser's criterion (Kaiser, 1958) of retaining the components with eigenvalues greater than one. The Kaiser's criterion seemed to be applicable here as the number of variables is less than 30 (SPSS 2009). The Kaiser-Meyer-Olkin measure of sampling adequacy is found to be 0.645 ( $>0.5)$ suggesting the samples are adequate. The Bartlett's Test of Sphericity is found to be highly significant 
Table 6. Varimax rotated factor loadings for five-factor solutions.

\begin{tabular}{lllrl}
\hline Factors & Variable Symbol & Variables & Selection & Factor Load \\
\hline Factor 1 & Awr_Total & Total Awareness & Yes & 0.972 \\
Variance $=19.61$ & Awr_Iron & Awareness about Iron Contamination & 0.906 \\
Eigenvalue =5.62 & Awr_Arsn & Awareness about Arsenic Contamination & 0.904 \\
& Awr_Path & Awareness about Pathogenic Contamination & & 0.778 \\
\hline Factor 2 & Avg_Edu & Average Education Level of the Family & Yes & 0.830 \\
Variance $=19.25$ & WTP & Willingness to Pay & Yes & 0.828 \\
Eigenvalue $=3.98$ & PC_Incm & Monthly Per Capita Income of the Family & 0.796 \\
& Total_Incm & Monthly Total Income of the Family & 0.780 \\
& Low_Edu & Lowest Education Level in the Family & 0.695 \\
& High_Edu & Highest Education Level in the Family & 0.691 \\
\hline Factor 3 & WQI_DC & Water Quality Index for Drinking and Cooking & Yes & 0.844 \\
Variance $=18.79$ & Buy_Amt & Amount of Water Bought Per Month & Yes & 0.822 \\
Eigenvalue $=2.25$ & Buy_Mony & Money Spent for Buying Water Per Month & Yes & 0.743 \\
& Dfclt_DC & Degree of Difficulty with Drinking / Cooking & Yes & -0.720 \\
& Exp_DC & Years of Using the Drinking and Cooking water & Yes & -0.718 \\
\hline Factor 4 & High_Age & Highest Age in the Family & & 0.855 \\
Variance $=11.03$ & Fam_Size & Number of Members in the family & Yes & 0.684 \\
Eigenvalue $=1.76$ & & & & 0.908 \\
\hline Factor 5 & Low_Age & Lowest Age in the Family & Yverage Age of the Family & 0.708 \\
Variance $=10.70$ & Avg_Age & & & \\
Eigenvalue $=1.46$ & & & & \\
\hline
\end{tabular}

$(p<0.001)$ suggesting Factor Analysis is appropriate (SPSS 2009) in this case. The analysis extracted five factors with eigenvalues greater than one which together accounted for $79.38 \%$ of the explained variance. The average communality after extraction has found to be 0.84 (>0.6) conforming to Kaiser's criterion. The details of factor loadings, explained variance and eigenvalues of the five extracted factors are given in Table 6. The items with loadings greater than 0.6 , are used to define five extracted factors. The variables for the regression of WTP are decided based on the extracted factors and are indicated in Table 6.

\subsubsection{Multiple regression}

A multiple regression analysis has been conducted for WTP against ten explanatory variables selected from the factor analysis presented in Table 6. The mean and standard deviation for the selected variables as obtained from the survey is presented in Table 7 . The $R^{2}$ for the regression is found to be 0.63 . The analysis of variance (ANOVA) is presented in Table 8 and seems to be acceptable for such studies. The regression equation for WTP is presented in Eq. (2).

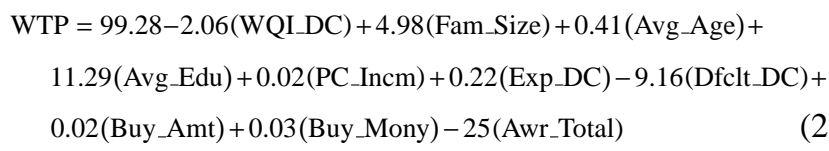

Table 7. Variables statictics for multiple regression.

\begin{tabular}{lrr}
\hline Variables & Mean & Standard Deviation \\
\hline WQI_DC & 82.90 & 9.97 \\
Fam_Size & 4.55 & 1.60 \\
Avg_Age & 36.42 & 7.86 \\
Avg_Edu & 4.87 & 1.64 \\
PC_Incm & 2145.35 & 2883.28 \\
Exp_DC & 9.87 & 8.91 \\
Dfclt_DC & 1.93 & 1.24 \\
Buy_Amt & 306.24 & 274.54 \\
Buy_Mony & 125.22 & 110.42 \\
Awr_Total & 7.63 & 2.54 \\
WTP & 58.51 & 84.27 \\
\hline
\end{tabular}

The explanatory variables as shown in Table 7 are employed in Eq. (2) for conducting a Monte Carlo's simulation. The monthly per family WTP is found to be $58.51 \pm 67.43$. A sensitivity analysis has been carried out and the tornado diagrams for regression coefficients and Spearman rank correlation coefficients are presented in Fig. 4.

The WTP is found to be most sensitive on per capita income (PC_Incm) and the least on awareness (Awr_Total). It has been hypothesized that the income would considerably 
Table 8. ANOVA for multiple regression.

\begin{tabular}{lccccc}
\hline & Df & SS & MS & F & Significance $F$ \\
\hline Regression & 10 & 450256.1 & 45025.61 & 15.59652 & $8.10 \times 10^{-16}$ \\
Residual & 90 & 259821.1 & 2886.901 & & \\
Total & 100 & 710077.2 & & & \\
\hline
\end{tabular}
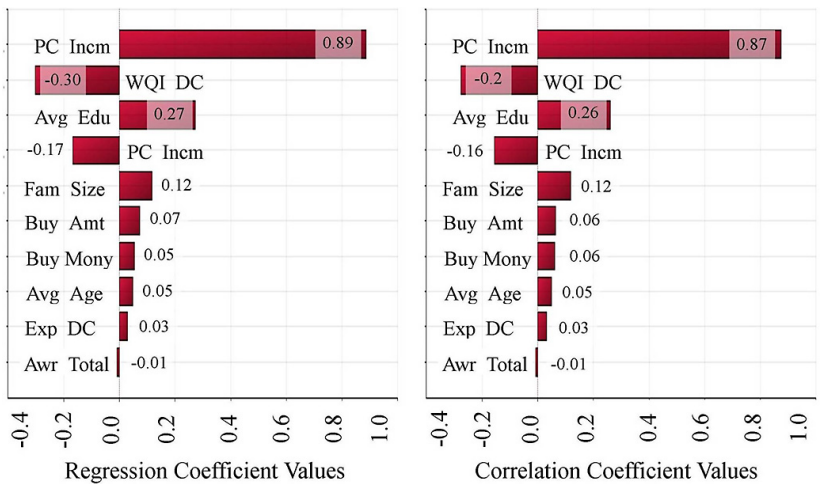

Figure 4. Tornado diagrams for sensitivity analysis of WTP

increase in the peri-urban areas with the growth of urbanizations. Such increase should be considered in CBA particularly for the peri-urban areas where the effect would be pronounced to reflect the effect of the expansion of the city with time. Dynamic analysis technique is used for estimating the increase of such income.

\subsection{Dynamic system analysis}

The observed WTP is dependant upon variables like income which changes over time. As a result WTP is likely to change over time as well. System dynamics analysis (SD) has been used to estimate the change of WTP with time. SD analysis was first proposed by Forrester (1991). It is a methodology for studying complex feedback systems over time. He applied SD to urban planning (Forrester, 1969) for its ability for long term effectiveness. Ho et al. (2007) chose SD after evaluating other optimizing models in connection with the conjunctive use of surface and subsurface water. They found that the SD model is a suitable methodology for constructing complex water resources models.

There are number of commercial software that has been developed for SD model. In this case, iThink (iSee 2009) has been used. It is a common SD application that has been used in several water quality books (Carlseen, 2004; Werick, 1994; Wurbs, 1994) and used by institutes like (UNESCOIHE, 2010). In the present study, iThink (iSee 2009) software is used for analyzing system dynamics of income growth with time.

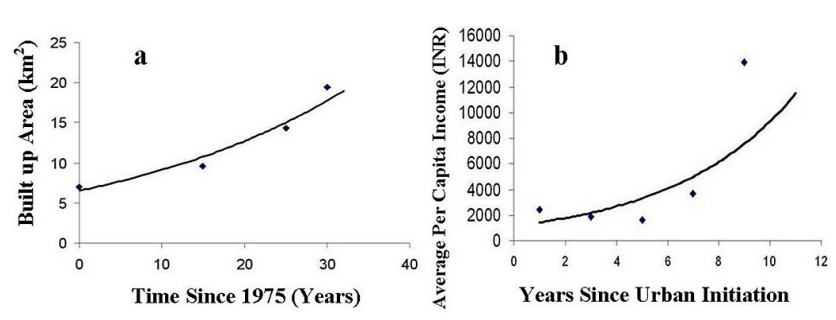

Figure 5. Trends of income and urban growths.

\subsubsection{Urbanization and income growth}

The growth of urbanization results in increase of built up areas. Such growth for peri-urban Kolkata has been estimate by Bhatta (September 2009) from satellite data and is presented in Fig. 2. The data has been combined with the geographical data for development of the regression based relationship presented in Eq. (3) and in Fig. 5a. The correlation $\left(R^{2}\right)$ has been found to be 0.96 .

$B=6.5295 e^{0.0333 t_{a}}$

where $B=$ built up area in $\mathrm{km}^{2}$ and $t_{a}=$ time in years since 1975.

Using Eq. (3) present built-up area (at year 2010) is calculated as $20.9435 \mathrm{~km}^{2}$. The income and years of urbanization have been studied from the WTP survey data conducted in the eastern fringe of Kolkata viz. Mukundapur. A relationship is derived from regression as shown in Eq. (4) and in Fig. 5b. It has been observed that the average income of the population migrating to this area would increase as presented in Fig. $5 \mathrm{~b}$. The correlation $\left(R^{2}\right)$ has been found to be 0.58 . It is so expected because only progressively richer people could afford the price increase caused for rapid urbanization in this area.

$S=1172 e^{0.2074 t_{i}}$

where $S=$ Average per capita income and $t_{i}=$ time in years of urbanization.

\subsubsection{Dynamic simulation}

The increase in built up area and per capita income in the fringes of Kolkata with the years of urbanization is evaluated over a period of 20 years in an iThink (2009) dynamic simulation model as shown in Fig. 6. 


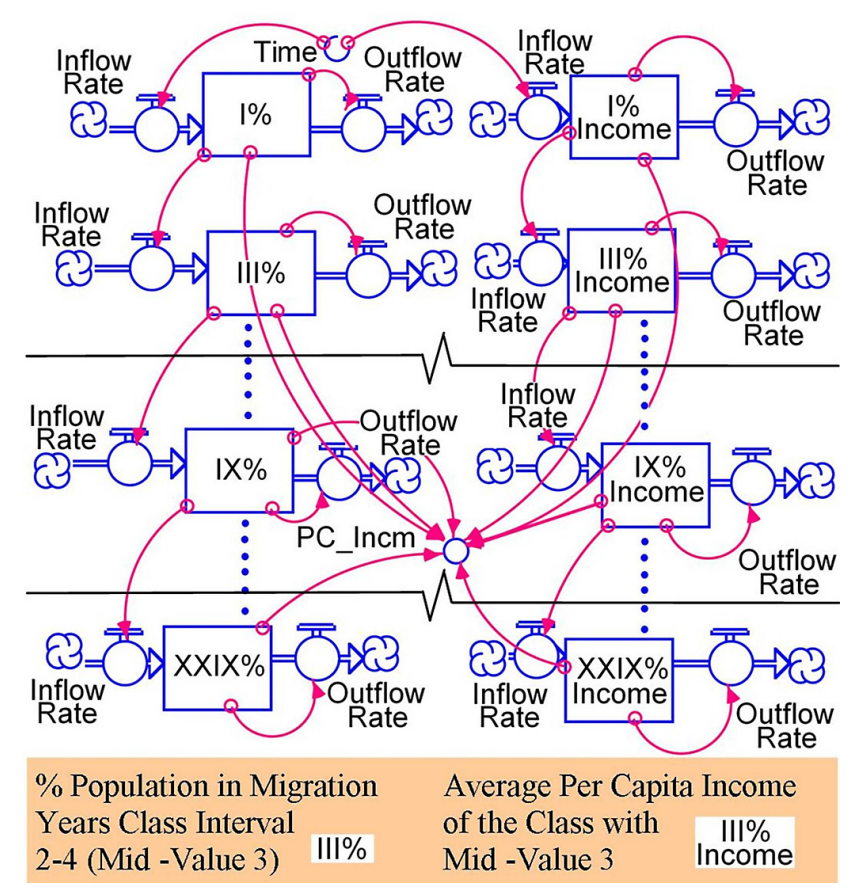

Figure 6. Dynamic simulation model in iThink.

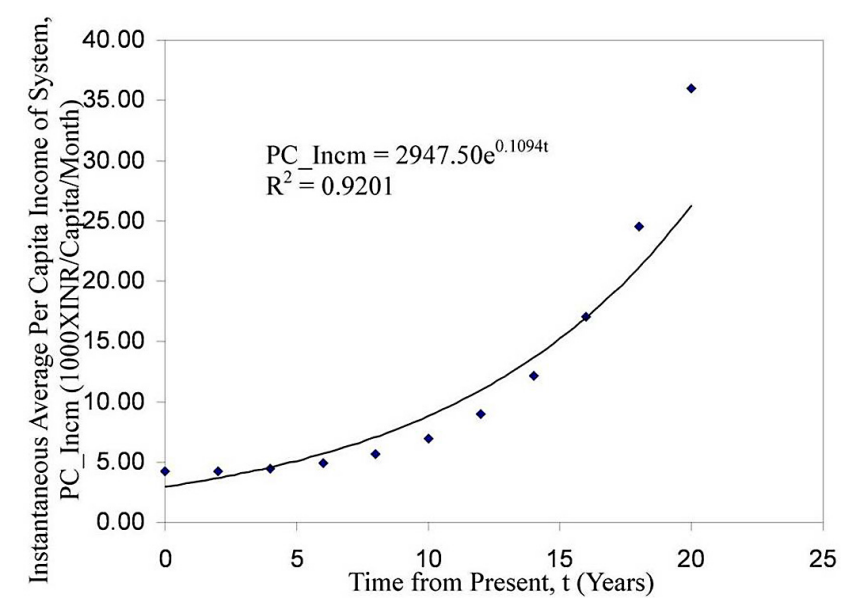

Figure 7. iThink model results.

The iThink software automatically simulates a time dependent dynamic system, comprising different input variables (shown in Fig. 6) based on assigned relationships. The model component relationships are presented in Table 9.

The model is simulated for ten time steps i.e. for 20 years and the average per capita incomes are presented in Table 10 and increase of income with time is presented in Fig. 7.

The regression relationship between incomes with time is presented in Eq. (13). The correlation $\left(R^{2}\right)$ is found to be 0.92 .

PC_Incm $=2947.5 e^{0.1094 t}$ where, PC_Incm=Instantaneous Average Per Capita Income of the System (INR/Capita/Month), $t=$ Year of Calculation (time in year from recent).

\subsection{WTP estimate}

The questionnaire survey conducted in the eastern fringes of Kolkata viz. Mukundapur provided the opportunity to estimate the WTP by regressing against the income as presented in Eq. (14) and based on Eq. (13) it is rewritten as in Eq. (15). The daily per capita WTP is presented in Eq. (16). Since the daily per capita water demand is $150 \mathrm{lpcd}$ (CPHEOO, 1999) the WTP per cubic meter of water may be written as in Eq. (17).

$\mathrm{WTP}_{\mathrm{m}}=0.0211 \mathrm{PC} \_$Incm +6.1137

$\mathrm{WTP}_{\mathrm{m}}=0.0211\left(2947.5 e^{0.1094 t}\right)+6.1137$

$\mathrm{WTP}_{\mathrm{d}}=\frac{\mathrm{WTP}_{\mathrm{m}} \times 12}{365 \times \text { Fam_Size }}$

$\mathrm{WTP}_{0}=\frac{\left(\mathrm{WTP}_{\mathrm{d}}\right) \times 1000}{150}$

where, $\mathrm{WTP}_{\mathrm{m}}=$ Monthly per Family WTP (INR/Family/ Month) and PC_Incm = Monthly per family income (INR/ Family/Month), $\mathrm{WTP}_{0}=$ WTP per cubic meter of water (INR/CuM).

\section{Benefit cost comparison}

\subsection{Net present value}

The present value of WTP after correction for inflation for each cubic meter of water is estimated from Eq. (17) and presented in Eq. (18). The net present value of WTP for each cubic meter is presented in Eq. (19).

$\mathrm{WTP}_{\mathrm{p}}=\frac{\sum_{T=1}^{75} \frac{\mathrm{WTP}_{0}(1+r)^{T}}{(1+i)^{T}}}{T}$

$\mathrm{NPV}=\mathrm{WTP}_{\mathrm{p}}-C p$

where, $\mathrm{WTP}_{\mathrm{p}}=$ Present value of WTP for each CuM of water, $r=$ average inflation rate, $T=$ Expected life of the water treatment facility for which CBA is conducted, $C p=$ present value of cost of the facility for which CBA is conducted.

The WTPp (Eq. 18) is simulated over time as presented in Fig. 8a. The graphs in Fig. 8b-d show the variation of NPV of WTP for each CuM of water (Eq. 19) over time. The range between \pm three standard deviation has been also presented as bands in Fig. 8. The costs of the facilities for booster stations in Kamalgazi, Begampur and Krishnamohanpur are obtained from the ANN model presented in Table 4. 
Table 9. Relationships in iThink model.

\begin{tabular}{|c|c|c|}
\hline Model Component Description & Relationships & Eq. No. \\
\hline Built up Area in $\mathrm{km}^{2}(B)$ & $B=6.5295 e^{0.0333\left(2 t_{i}+35\right)}$ & (5) \\
\hline The rate of increase in built up area & $\frac{d B}{d t_{i}}=0.4349 e^{0.0333\left(2 t_{i}+35\right)}$ & (6) \\
\hline Percentage of city population migrating to fringe areas $(P)$ & $P=B \times \frac{100}{20.9435}$ & (7) \\
\hline Migrants increase rate & $\frac{d P}{d t_{i}}=\frac{d B}{d t_{i}} \times \frac{100}{20.9435}$ & (8) \\
\hline By Eqs. (6) and (8) & $\frac{d P}{d t_{i}}=2.0764 e^{0.0333\left(2 t_{i}+35\right)}$ & (9) \\
\hline Per capita income of any first group from today $(S)$ & $S=1172 e^{0.2074\left(2 t_{i}+9\right)}$ & $(10)$ \\
\hline $\begin{array}{l}\text { Average per capita income increase rate of first group } \\
\text { with respect to iThink time step }\end{array}$ & $\frac{d S}{d t_{i}}=486.1456 e^{0.2074\left(2 t_{i}+9\right)}$ & $(11)$ \\
\hline $\begin{array}{l}\text { Instantaneous Average per Capita Income of the System } \\
\text { (INR/Capita/Month) }\end{array}$ & $\frac{\sum_{i i}^{i} \% \times i \% \mathrm{INCOME}}{\sum_{\forall i} i \%}, \quad i \in[I, I I I, V, \ldots . . X X I X]$ & $(12)$ \\
\hline
\end{tabular}

Note: All relations are with respect to iThink time scale ( 1 time step $=2$ years).

Where, $P=$ population migrating to the fringe area in percentage of the present population, $B=$ Built up area in $\mathrm{km}^{2}, S=$ Average per capita income of the migrants.

Table 10. iThink model results.

\begin{tabular}{rrr}
\hline $\begin{array}{r}\text { iThink } \\
\text { Time Steps }\end{array}$ & $\begin{array}{r}\text { Time } \\
\text { Years }\end{array}$ & $\begin{array}{r}\text { Average per Capita Income } \\
\text { (INR/Capita/Month) }\end{array}$ \\
\hline 0 & 0 & 4207.73 \\
1 & 2 & 4244.40 \\
2 & 4 & 4440.84 \\
3 & 6 & 4869.12 \\
4 & 8 & 5638.99 \\
5 & 10 & 6917.04 \\
6 & 12 & 8955.88 \\
7 & 14 & 12138.16 \\
8 & 16 & 17043.27 \\
9 & 18 & 24548.19 \\
10 & 20 & 35980.16 \\
\hline
\end{tabular}

\subsection{Risk}

The inputs for estimation of WTP and NPV are stochastic in nature. The common procedure for investigating such issues in CBA is by means of Monte Carlo's simulations (MCS). For example, Whittington et al. (2004) used MCS in Kathmandu, Nepal and Zhang (2009) used it in Singapore for water supply projects. MCS has been recommended by the regulatory authorities in counties like Canada (2007) and EU (Jasper, 2008). In MCS analysis, possible inputs depending upon its probability distributions are provided to the model and the resultant outcomes are noted. After numerous operations, the mean and standard deviations of the outcomes are assumed as the distributions of the possible outcome values.
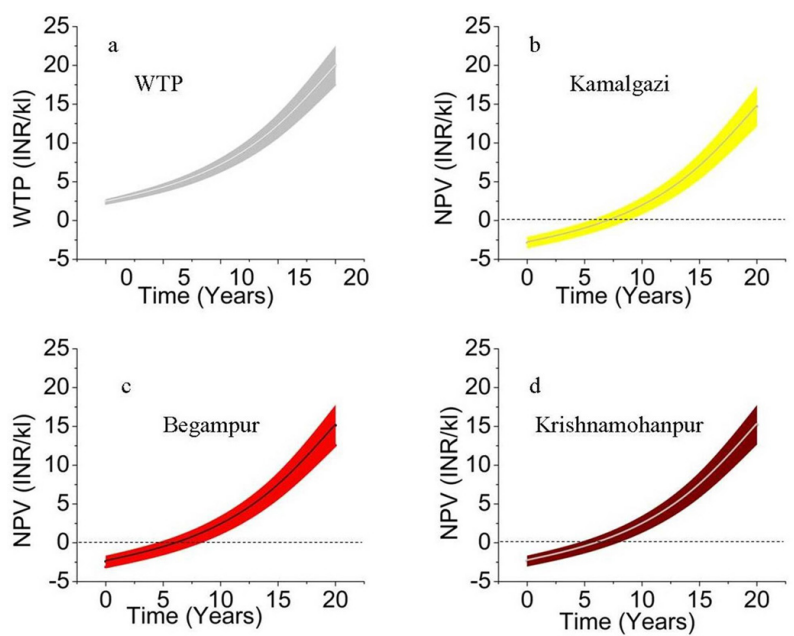

Figure 8. Variation of WTP and NPV with time.

The risks in inputs like the family size (Fam_Size), rate of inflation $(r)$, rate of discount $(i)$ are presented as triangular distribution in Table 11. The present value of ANN generated cost of supply $(C p)$ as shown in Table 5 are also presented. Monte Carlo's simulations consisting of 10000 iterations have been conducted by Palisade @ Risk (DTS, 2009) software for estimating the standard deviation of NPV as shown in Fig. 9. The results of the Eq. (19) for typical three cases have been presented in Fig. 9 as examples. 


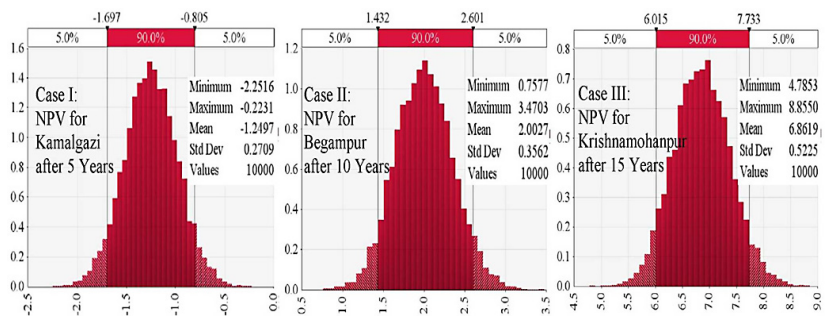

Figure 9. Distributions observed in typical simulation runs for NPV.

Table 11. Parameters for WTP and NPV simulation.

\begin{tabular}{llllc}
\hline Symbol & Unit & Low & Average & High \\
\hline Fam_Size & Number & 2.00 & 4.55 & 8.00 \\
$\mathrm{R}$ & $\%$ & 5.00 & 6.00 & 7.00 \\
$\mathrm{I}$ & $\%$ & 6.00 & 7.00 & 8.00 \\
$\mathrm{Cp}$ & INR/kl & Mean & Standard Deviation \\
& Kamalgazi & 5.2990 & \pm 0.2161 \\
& Begampur & 4.8360 & \pm 0.2166 \\
& Krishnamohanpur & 4.7970 & \pm 0.2056 \\
\hline
\end{tabular}

\subsection{Uncertainty}

The common procedure for investigating uncertainty in a CBA is done by means of sensitivity analysis (ADB, 1999; Baffoe-Bonnie, 2006; Canada, 2007; Florio, 2006). It identifies the critical parameters for the solution and determines systematically the influence of parameter variations on the solution (Fellin et al., 2005). The guidelines of OECD (2006) also specified sensitivity study for CBA. Sensitivity analysis is an iterative process. The variables in Eq. (19) are changed systematically and the resultant NPV is recorded. After numerous iterations, the data set would provide an idea about the input which has the largest effect on the NPV. The 'Toprank' software of the Palisade system (DTS, 2009) has been used to conduct the sensitivity analysis. The results of the sensitivity analysis are presented in the tornado diagram in Fig. 10. The inflation and discount rate is found to be much more significant than other factors like project $\operatorname{cost}(C p)$. The power series relationship of inflation $(r)$ and discount $(i)$ in the NTP and the long time periods of 75 years have made it much more sensitive than other factors like the project cost.

\section{Result and discussion}

A previous CBA study (Dutta Roy et al., 2010) conducted for the city of Kolkata has been extended for the peri-urban areas in this article. The block diagram presented in Fig. 1 has been followed for a CBA methodology suitable to periurban areas. The urbanization is taking place rapidly in the

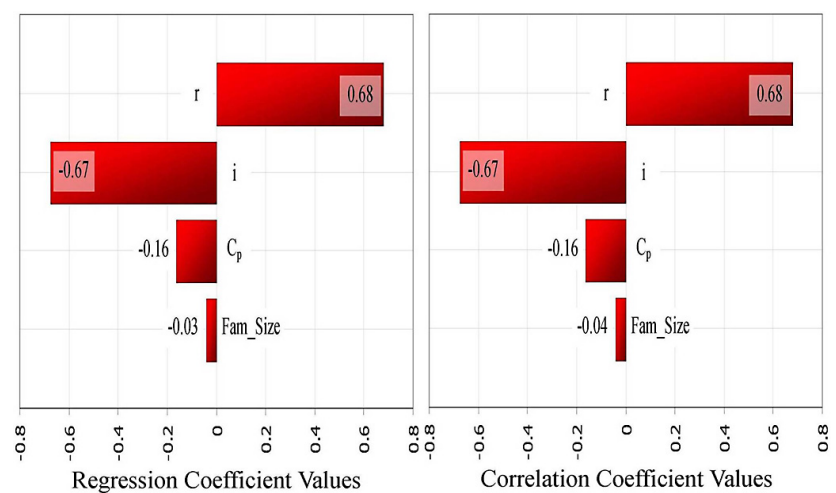

Figure 10. Tornado diagrams for sensitivity analysis of NPV.

suburbs of Kolkata as evidenced from Fig. 2 derived from the satellite data (Bhatta, September 2009). In the peri-urban areas, people mostly depend on ground water from individually owned bore wells or surface water from ponds. Only pockets of suburbs have small groundwater based piped water systems installed mainly by external grants (IBRD, 1973). The water samples from these sources have been tested according to standard methods (APHA, 1995), compared with the national standards (CEEPHO, 1999) and presented in Table 3.

It may be noted from Table 3 that water quality of the fringe areas are inadequate in a number criteria prescribed in the Indian standards (CEEPHO, 1999). WQI has therefore been used for simplifying the quality issues about variable by variable comparisons. Canadian WQI method (CCME, 2001) as presented in Table 4 and calibrated to Indian standards has been used in the present case. It is observed in Table 3 that the WQI of water from pond or well in the fringe areas are of "poor" quality. The WQI has been found to be improved to about "fair" quality for ground water. The piped surface water obtained from the treatment plant on the other hand has the WQI of above 90 indicating "good" quality. The users in the suburbs would naturally prefer piped surface water. In order to explore the consumers' preferences a water quality survey has been conducted in the peri-urban areas. It has been found from the survey that a large percentage of people actually buy water and most have a positive WTP for treated surface water.

In our previous study (Dutta Roy et al., 2010) a neural network model has been developed for rapid estimation of water supply network costs. The model has been employed for estimating costs of the booster pumping stations in the DRWW network as shown in Table 4.

The benefit of the water supply has been initially estimated from a WTP survey. Varieties of queries about the water supply have been added to the survey. A factor analysis presented in Table 6 indicates that five factors would account for about $80 \%$ of the variance. The multiple regression study with ten explanatory variables as selected in Table 6 has been conducted and the regression relationship is 
presented in Eq. (2). The mean and standard deviation for the selected explanatory variables as obtained from the survey is presented in Table 7. These statistics have been used for conducting a Monte Carlo's simulation of the Eq. (2). A sensitivity analysis has been carried out and a tornado diagram has been presented in Fig. 4. The WTP is found to be most sensitive on per capita income of the surveyed population.

The high dependence of WTP on income has created a special problem for the peri-urban areas. Since urbanizations are taking place rapidly in peri-urban areas as indicated in Fig. 2 the per capita income are also increasing faster in these areas. The CBA of a water supply project based on the present per capita income of the surveyed population may not be appropriate only after a few years because of increased per capita income caused by urbanizations. Since the water supply projects are usually for a long period of time the increase of per capita income with urbanizations should also be included for a realistic CBA.

A SD analysis has been conducted for ascertaining the increase of per capita income with time and the results have been plotted in Fig. 7. The regression relationship between income and time as derived from SD analysis is presented in Eq. (13). It may be noted that this per capita income rise in the peri-urban area is from the result of urbanization because progressively richer people could afford housing in these areas. The income rise as a result of inflation is a different issue and has been addressed in the present value estimate analysis in Eq. (18). The cost derived from Table 4 and the benefits derived from Eq. (13) has been used in Eq. (19) for estimating the net present value and the results are presented in Fig. 8.

It may be noted in Fig. 8 that NPV for each of the booster stations in the DRWW network namely Kamalgazi, Begampur and Krishnamohanpur are negative at the start. These projects should normally be rejected in a standard CBA. However, the NPV for each of these projects become positive after about 5-10 years because of increase of per capita income in the area as a result of urbanization as shown in Fig. 8. The impact of urbanizations should therefore be included in the CBA conducted in the peri-urban areas.

A Monte Carlos simulation of Eq. (19) has been conducted for estimating the risks associated with the NPV. Triangular distribution of risks for input variables like inflation and interest rates have been considered. The mean and standard deviation of the NPV for the three numbers booster pumping stations in the DRWW network are presented in Table 11. The distributions of the NPV for three typical cases have been presented in Fig. 9. The uncertainty associated with the NPV is investigated in the Tornado diagram in Fig. 10. The inflation and discount rate is found to be most significant. The power relationship of inflation $(r)$ and discount $(i)$ with NPV have made these more sensitive than other factors.

\section{Conclusions}

The development of the infrastructures like water supply is a challenge for mega cities in the developing world where urbanizations are taking place rapidly. Continuous expansion of the city area makes the project implementations more complex. A standard CBA analysis may reject a number of proposals in the peri-urban areas in a developing country mainly because of lesser WTP at the time of CBA. However, the urbanization of the area might change the financial characteristics and the resultant WTP may be sufficient to affirm a project otherwise unviable. The factors of such urbanizations are not included in a CBA methodology recommended in developed countries like US (Kopp et al., 1997) or EU countries (Baffoe-Bonnie et al., 2006), (Florio, 2006) probably because the developed world does not face such acute urbanization pressure in the peri-urban areas. However, the experience in Kolkata as presented in this article seems to show that these factors should be included in the peri-urban areas of the developing countries.

Acknowledgements. The authors thank Anupam Debsarkar, Nakibul Hossain Mondal, Nasim Mondal, Prasanta Mondal and Gitali Sarkar for extending their support and cooperation in carrying out the sample survey for the study.

Edited by: A. Verliefde

\section{References}

Asian Development Bank (ADB): Handbook for the Economic Analysis of Water Supply Projects, http://www.adb.org/ documents/handbooks/water_supply_projects/default.asp (last access: 30 March 2010), 1999.

Adeli, H.: Neural networks in civil engineering: 1989-2000, Comput.-Aided Civ. Inf., 16, 126-142, 2001.

Argent, R. and Houghton, B.: Land and water resources model integration: software engineering and beyond, Adv. Environ. Res., 5, 4, 351-359, 2001.

Antony, J., Kumar, V., Pathan, S., and Bhanderi, R. J.: Spatiotemporal analysis for monitoring urban growth - a case study of Indore city, J. Indian Soc. Remote Sens., 35, 1, 11-20, 2007.

American Public Health Association (APHA): Standard Methods for the Examination of Water and Wastewater, 19th Edn., USA, 1995.

Baffoe-Bonnie, B., Harle, T., Glennie, E., Dillon, G., and Sjovold, F.: Framework for operational cost benefit analysis in water supply, TECHNEAU, contract number 018320, 2006.

Banerjee, A. and Das, S.: Population environment and development: some issues in sustainability of Indian mega-cities of New Delhi and Kolkata (Calcutta), http://epc2006.princeton.edu/ download.aspx? ?submissionId=60139 (last access: 30 July 2010), 2006.

Basu, S. R. and Main, H. A. C.: Calcutta's water supply: demand, governance and environmental change, Appl. Geogr., 21, 23-44, 2001.

Bhattacharya, P., Chatterjee, D., and Jacks, G.: Occurrence of arsenic-contaminated groundwater in alluvial aquifers from delta 
plains, eastern India: options for safe drinking water supply, J. Water Resour. Dev., 3, 79-82, 1997.

Bhatta, B., Saraswati, S., and Bandyopadhyay, D.: Quantifying the degree-of-freedom, degree-of-sprawl, and degree-of-goodness of urban growth from remote sensing data, Appl. Geogr., 30, 1, 96$111,2010$.

Bhatta, B.: Modelling of urban growth boundary using geoinformatics, Int. J. Digital Earth, 2, 4, 359-381, 2009.

Bhatta, B.: Analysis of urban growth pattern using remote sensing and GIS: a case study of Kolkata, India, Int. J. Remote Sens., 30, 8, 4733-4746, 2009.

Bureau of Indian Standard (BIS): BIS10500-1991, Indian Standard Drinking Water - Specification, 2003.

Boussabaine, H.: The use of artificial neural networks in construction, Constr. Manage. Econ., 14, 427-436, 1996.

Brouwer, R.: Do stated preference methods stand the test of time? A test of the stability of contingent values and models for health risks when facing an extreme event, Ecol. Econ., 60, 399-406, 2006.

Carlsen, W.: Watershed Dynamics. Cornell Scientific Enquiry Series, NSTA Press, USA, 2004.

President of the Treasury Board (Canada): Canadian costbenefit analysis guide regulatory proposals, http://sciencepolicy. colorado.edu/students/envs_5120/CanadaCBA.pdf (last access: 21 September 2010), 2007.

Canadian Council of Ministers of the Environment (CCME): CCME water quality index 1.0 User's Manual, http://www.ccme. ca/ourwork/water.html?category_id=102 (last access: 30 June 2010), 2001.

Central Ground Water Board (CGWB): Ground Water Information Booklet, Kolkata Municipal Corporation, West Bengal, http://cgwb.gov.in/District_Profile/WestBangal/Kolkata\%

20Municipal\%20Corporation.pdf (last access: 30 July 2010), 2007.

Chatterjee, A., Das, D., Mandal, B. K., Roy Chowdhury, T., Samanta, G., and Chakraborti, D.: Arsenic in ground water in six districts of West Bengal, India: the biggest arsenic calamity in the world. Part I. Arsenic species in drinking water and urine of the affected people, Analyst, 120, 643-650, 1995.

Chung, G., Lansey, K., Blowers, P., Brooks, P., Ela, W., Stewart, S., and Wilson, P.: A general water supply planning model: evaluation of decentralized treatment, Environ. Model. Softw., 23, 893-905, 2008.

Cohen, B.: Urbanization in developing countries: current trends, future projections, and key challenges for sustainability, Technol. Soc., 28, 63-80, 2006.

Costanza, R. and Ruth, M.: Using dynamic modeling to scope environmental problems and build consensus, J. Environ. Manage., 22, 2, 183-195, 1998.

Central Public Health and Environmental Engineering Organization (CPHEEO): Manual on Water Supply and Treatment. Third Edition, Ministry of Urban Development, The Government of India, New Delhi, 1999.

Dietrich, B. and Henderson, J.: Urban Water Supply Conditions and Needs in Seventy-five Developing Countries, World Health Organization, Geneva, 1963.

Decision Tools Suite (DTS): Palisade Corporation, Ithaka, New York, USA, http://www.palisade.com/ (last access: 13 January 2010), 2009.
Dutta Roy, K. and Chakrabarty, S.: Assessment of production cost of municipal water: some case study, J. Inst. Public Health Eng., 07, 4, 16-19, 2006.

Dutta Roy, K., Thakur, B., Konar, T. S., and Chakrabarty, S. N.: Rapid evaluation of water supply project feasibility in Kolkata, India, Drink. Water Eng. Sci., 3, 29-42, doi:10.5194/dwes-3-292010, 2010.

Emblemsvåg, J.: Life-Cycle Costing Using Activity-Based Costing and Monte Carlo Methods to Manage Future Costs and Risks, John Wiley \& Sons, Inc., 2003.

Fellin, W., Lessmann, H., Oberguggenberger, M., and Vieider, R.: Analyzing Uncertainty in Civil Engineering, Springer, Berlin, 2005.

Florio, M., Finzi, U., Genco, M., Levarlet, F., Maffii, S., Tracogna, A., and Vignetti, S.: Guide to Cost-Benefit Analysis of Investment Projects, Evaluation Unit, DG Regional Policy, European Commission, 2006.

Forrester, J.: System Dynamics and the Lessons of 35 Years, Sloan School of Management, Massachusetts Institute of Technology, 1991.

Forrester, J.: Urban Dynamics, Pegasus Communications, 1969.

Fuller, S. and Petersen, S.: Energy Price Indices and Discount Factors for Life-Cycle Cost Analysis - April 2002, US Govt., NST Handbook 135 http://fire.nist.gov/bfrlpubs/build02/PDF/ b02017.pdf (last access: 30 July 2010), 2002.

Gessler, M. and Brighu, U.: Monitoring Public Providers for the Poor, Case Study 1: Jaipur, India, Regulating Water and Sanitation for the Poor: Economic Regulation for Public and Private Partnerships, edited by: Franceys, R. and Gerlach, E., Earthscan, London, 2008.

Guha, S.: Valuation of clean water supply by willingness to pay method in a developing nation: a case study in calcutta, India, J. Young Invest., 17, 4, http://www.jyi.org/research/re.php?id= 1295 (last access: 25 June 2010), 2007.

Ho, C., Yang, C., Chang, L., and Yeh, M.: System Dynamics Modeling of the Conjunctive-Use of Surface and Subsurface Water, World Environmental and Water Resources Congress, 2007, Restoring Our Natural Habitat, ASCE, Tampa bay, Florida, USA, 2007.

IBRD: Appraisal of the Calcutta Urban Development Project, Washington DC, USA, 27 July, 1973.

isee system: iThink and Stella, systems thinking for education and research, http://www.iseesystems.com/softwares/Education/ StellaSoftware.aspx (last access: 30 July 2010), 2009.

Jaspers: Guidelines for Cost Benefit Analysis of Water and Wastewater Projects to be Supported By The Cohesion Fund And The European Regional Development Fund in 2007-2013, http://discutii.mfinante.ro/static/10/Mfp/evaluare/ Water_WasteWater_GuideFINAL.pdf (last access: 21 September 2010), 2008.

Kaiser, H.: The Varimax Criterion for Analytic Rotation in Factor Analysis, Psychometrika, 23, 187-200, 1958.

Kolkata Municipal Corporation for the Asian Development Bank (KMC): Environmental Assessment Report: Kolkata Environmental Improvement Project (Supplementary Financing), Project Number: 29466, August 2006.

Kolkata Municipal Corporation for the Asian Development Bank (KMC): Project Administration Memorandum for the Supplementary Loan: Kolkata Environmental Improvement Project, 
June 2007.

Kopp, R. J., Krupnick, A. J., and Toman, M.: Cost-Benefit Analysis and Regulatory Reform: An Assessment of the Science and the Art, Discussion Paper 97-19, Resources for the Future, Washington, DC, USA, 1997.

Lata, K. M., Prasad, V. K., Badarinath, K. V. S., and Raghavaswamy, V.: Measuring urban sprawl: a case study of Hyderabad, http://www.gisdevelopment.net/application/ urban/sprawl/urbans0004.htm, last access: 30 July 2010.

Llorente, M. and Zerah, M.: The urban water sector: formal versus informal suppliers in India, Urban India, Vol. XXIII, No. 1, National Institute Of Urban Affairs, January-June 2003.

Majumdar, C. and Gupta, G.: Willingness to pay and municipal water pricing in transition: a case study, J. Integr. Environ. Sci., 6, 4, 1-12, 2009.

NeuroDimensions Inc.: Neural network software, http://www.nd. com/ (last access: 31 July 2010), 2009.

Organization for Economic Co-operation and Development (OECD): Cost-Benefit Analysis and the Environment: Recent Developments, ISBN 92-64-01004-1, 2006.

Rajankar, P. N., Gulhane, S. R., Tambekar, D. H., Ramteke, D. S., and Wate, S. R.: Water quality assessment of groundwater resources in Nagpur region (India) based on WQI, E J. Chem., 6, 3, 905-908, 2009.

Ramakrshinaiah, C., Sadashivalah, C., and Ranganna, G.: Assessment of water quality index for the groundwater in Tumkur Taluk, Karnataka State, India, E J. Chem., 6, 2, 523-530, 2009.

Roy, J., Chattopadhyay, S., Mukherjee, S., Kanjilal, M., Samajpati, S., and Roy, S.: An economic analysis of demand for water quality: case of Kolkata, Econ. Polit. Weekly, January, 186-192, 2003.

Ruet, J.: Water supply and sanitation as "Urban Commons" in Indian metropolis: how redefining the State/Municipalities relationships should combine global and local de facto 'commoners', Centre de Sciences Humaines, New Delhi, India, 2002.

Society of Automotive Engineers (SAE): Reliability and Maintainability Guideline for Manufacturing Machinery and Equipment, M-110.2, Warrendale, PA, 1999.

Sahu, P. and Sikdar, P.: Assessment of aquifer vulnerability to groundwater pollution by multi-criteria analysis in and around East Calcutta Wetlands, West Bengal, India, Asian J. Water Environ. Pollut., 6, 2, 31-42, 2009.

Sargaonkar, A. and Deshpande, V.: Development of an overall index of pollution for surface water based on a general classification scheme in Indian context, Environ. Monit. Assess., 89, 43-67, 2003.
Sikdar, P., Sarkar, S., and Palchoudhury, S.: Geochemical evolution of groundwater in the quaternary aquifer of Calcutta and Howrah, India, J. Asian Earth Sci., 19, 5, 579-594, 2001.

Shekhar, S.: Urban sprawl assessment Entropy approach, Pune, http://www.archidev.org/article.php3?id_article=610, last access: 30 July 2010.

Statistical Package for the Social Sciences (SPSS): IBM 2009, Armonk, New York, USA, http://www.spss.com/, last access: 30 July 2010.

Sudhira, H., Ramachandra, T., and Jagadish, K.: Urban sprawl: metrics, dynamics and modelling using GIS, Int. J. Appl. Earth Obs. Geoinf., 5, 1, 29-39, 2004.

Turpie, J.: The existence value of biodiversity in South Africa: how interest, experience, knowledge, income and perceived level of threat influence local willingness to pay, Ecol. Econ., 46, 199216, 2003.

United Nations Environment Programme (UNEP): Global Drinking Water Quality Index Development and Sensitivity Analysis Report, United Nations Environment Programme, Global Environment, Monitoring System/Water Programme, 2007.

UNESCO-IHE Institute for Water Education: http://www.unesco-ihe.org/courses/module/ 5696F5400DF3040BC12575F60029C10E (last access: 30 July 2010), 2010.

US EPA: http://www.epa.gov/waterscience/standards/about/rev.htm (last access: 30 July 2010), 2010.

World Bank: Final Report: An Assessment of Social Aspect and Willingness to Pay, Project Preparation Studies for Calcutta Water Supply, Sewerage and Drainage Projects, World Bank Project No. P.O. 50648, Kolkata, 2001.

Werick, W.: Managing Water for Drought: National Study of Water Management During Drought, US Army Corps of Engineers, 1994.

Whittington, D., Lauria, D. T., Prabhu, V., and Cook, J..: An economic reappraisal of the Melamchi water supply project Kathmandu, Nepal, Portuguese Econ. J., 3, 157-178, 2004.

Wurbs, R.: Computer Models for Water-Resources Planning and Management: National Study of Water Management During Drought, US Army Corps of Engineers, 1994.

Zhang, S.: ArchitectingWater Supply System - A Perspective from Value of Flexibility, Second International Symposium on Engineering Systems, MIT, Cambridge, USA, 15-17 June 2009.

Zurada, M.: An Introduction to Artificial Neural Systems, PWS Publishing Company, Mumbai, India, 1992. 